\title{
Effects of Meloidogyne incognita, Alternaria dauci and Fusarium solani on Carrot in Different Types of Soil
}

\author{
L. AHMAD and Z. A. SIDDIQUI* \\ Department of Botany, Aligarh Muslim University, Aligarh-202002, India
}

(Received: 17 November 2016; accepted: 9 December 2016)

\begin{abstract}
Effects of Meloidogyne incognita, Alternaria dauci and Fusarium solani were studied on carrot (Daucus carota L.) growth, chlorophyll, carotenoid and proline contents in different types of soil. Plants grown in 20:80 and 40:60\% sand:clay soil mixtures showed a significant increase in root dry weight, chlorophyll and carotenoid contents compared to plants grown in 100\% clay soil. However, use of 60:40 sand:clay resulted in a similar root dry weight, chlorophyll and carotenoid contents as was found in carrots grown in 100\% clay soil. Inoculation of plants with $M$. incognita, A. dauci or F. solani caused a significant reduction in root dry weight, chlorophyll and carotenoid contents in all soil types as compared to their respective control. Inoculation of plants by $A$. dauci caused the greatest reduction in root dry weight followed by F. solani and M. incognita in different sand and clay mixtures. Use of 20:80, 40:60 or 60:40 sand:clay mixtures caused a significant increase in proline content of plants over those grown in $100 \%$ clay soil. Similarly, inoculation of M. incognita, A. dauci and $F$. solani caused a significant increase in proline content in all soil types compared to their respective control.
\end{abstract}

Keywords: Carotenoids, chlorophyll, clay, proline, sand.

Carrot (Daucus carota L.) is one of the popular vegetables in many countries and had important nutritional value (Al-Harbi et al., 1997). It is being consumed mainly due to their pleasant flavour and perceived health benefits related to minerals, fibre and vitamins including vitamin B and beta carotene that promotes the synthesis of vitamin A. Carrot is an excellent source of iron, calcium, phosphorus, folic acid and sugars (Yawalker, 1992).

Various plant pathogens cause damage on carrot. Important fungal diseases of carrot includes Alternaria leaf blight caused by Alternaria dauci; black root rot by Thielaviopsis basicola; black rot by Alternaria radicina; cavity spot by Pythium spp.; Cercospora leaf spot by Cercospora carotae; cottony rot by Sclerotinia sclerotiorum and root rot by Fusarium spp (Koike et al., 2006). Among nematodes, root-knot nematode species Meloidogyne hapla, M. javanica and $M$. incognita are of worldwide economic importance for carrot cultivation (Abawi et al., 2009) and impacting both the quantity and quality of marketable carrot yield (Sasser and Carter, 1985). Attacks by M. javanica and M. incognita prevail in tropical and sub-tropical areas of the world (Rubatzky et al., 1999).

*Corresponding author; e-mail: zaki_63@yahoo.co.in 
Soil type and texture is recognized as an important factor that affects both crop productivity and plant pathogens including plant parasitic nematode communities (Koenning and Barker, 1995). Soil texture largely determines soil moisture holding capacity and aeration and has impacts on the nematode's ability to hatch, move through soil, locate and penetrate a host, and mate (Koenning and Barker, 1995). Thus, soil type influences the damage potential of several nematodes (Koenning et al., 1988). Soils that hold generous amount of water are less subject to leaching losses of nutrients. After a soil is saturated with water, all of the excess water and some of the nutrients that are in soil solution are leached downward in soil profile. In addition, soil texture is a reflection of the particle size and small particles (clay and silt) have a much larger surface area than the larger sand particles. This large surface area allows the soil to hold a greater quantity of water.

During the course of survey of carrot fields of Aligarh district for plant parasitic nematodes and fungi, we found frequent occurrence of $M$. incognita (Kofoid and White) Chitwood, A. dauci (J.G. Kühn) Rostrup and F. solani (Martius) Sacc. in different fields having different type of soil. It was thought desirable to study the effect of these pathogens individually and carrot growth, chlorophyll, carotenoids and proline contents in different soils types.

\section{Materials and Methods}

\section{Plant culture}

Soil mixtures containing clay soil and sand in the ratio of 100\% clay soil, 80:20 clay:sand, 60:40 clay:sand and 40:60 (v/v) clay:sand mixtures were prepared and autoclaved. Later, the mixtures were fertilized with inorganic fertilizers at the rate of $0.03 \mathrm{~g}$ $\mathrm{N}, 0.04 \mathrm{~g} \mathrm{~K}$ and $0.05 \mathrm{~g} \mathrm{P}$ per kg soil. Seeds of carrot cv. Rose red were surface sterilized with $0.01 \%$ mercuric chloride for 2 minutes and washed three times in distilled water. Sowing of seeds was done in different soil mixtures placed in $15-\mathrm{cm}$ pots. One week after germination thinning was done to maintain single plant per pot. Two days after thinning seedlings were inoculated with Meloidogyne incognita, Alternaria dauci and Fusarium solani. Each treatment was replicated five times. Pots were placed on a glass house bench maintained at $25{ }^{\circ} \mathrm{C}$. Pots were watered as needed and experiment was terminated 90 days after inoculation.

\section{Nematode inoculum}

M. incognita was collected from carrot field and multiplied on egg plant (Solanum melongena L.) using a single egg-mass from a single female. Egg-masses were handpicked using sterilized forceps and placed in $9-\mathrm{cm}$ diameter sieves of $1-\mathrm{mm}$ pore size which were previously mounted with cross layered tissue paper for hatching. These sieves were placed in Petri dishes containing distilled water and kept in an incubator at $27{ }^{\circ} \mathrm{C}$. In the experiment, 2000 freshly hatched second stage juveniles of M. incognita were inoculated as described below. 


\section{Maintenance and preparation of fungal inocula}

Pure cultures of F. solani and A. dauci were obtained from the Division of Mycology and Plant Pathology, Indian Agricultural Research Institute, New Delhi. The cultures were maintained on Petri dishes containing potato dextrose agar media and incubated in an incubator at $25{ }^{\circ} \mathrm{C}$. For obtaining sufficient inoculums, $F$. solani and A. dauci were cultured separately on Richards liquid medium (Riker and Riker, 1936) at $25 \pm 1{ }^{\circ} \mathrm{C}$ for 15 days. After sufficient growth of fungus, the liquid medium was filtered through Whatman filter paper 1 . The mat of fungal mycelium was washed in distilled water and was collected on blotting sheets to remove excess of water and nutrients. The inoculum was prepared by mixing $10 \mathrm{~g}$ fungal mycelium in $100 \mathrm{ml}$ distilled water for $30 \mathrm{~s}$ in a Waring blender. Ten $\mathrm{ml}$ of this suspension containing $1 \mathrm{~g}$ of fungus was used as inoculum. The inoculated plants were then transferred to glasshouse benches, watered regularly and assessed for the development of the disease.

\section{Inoculation techniques}

Soil around the roots was carefully removed and suspensions of $M$. incognita, $A$. dauci and F. solani were poured around the roots uniformly and soil replaced. In control pots, water was poured in similar amount to inoculum suspension. The four soil types were inoculated with $M$. incognita, A. dauci and F. solani alone and a control. There were 16 treatments, i.e. 4 types of soil $\times 4$ treatments including control. Each treatment was replicated five times, i.e. $16 \times 5=80$ pots in a complete factorial design.

\section{Observations}

The plants were harvested 90 days after inoculation. Data on plant length, plant fresh weight, dry weight, number of galls, nematode population, chlorophyll, carotenoids and proline contents were recorded. Root rot and blight indices and nematode population were also recorded. The length of plants was recorded in $\mathrm{cm}$ from the top of the first leaf to end of the root. Excess water was removed by blotting before weighing the plant for fresh weight. The plants were cut with a knife above the base of the root emergence zone to separate shoot and root. Shoots and roots were kept in envelopes at $60{ }^{\circ} \mathrm{C}$ for $2-3$ days before weighing the plants for dry weight. A $250 \mathrm{~g}$ subsample of well-mixed soil from each treatment was processed by Cobb's sieving and decanting technique followed by Baermann funnel extraction (Southey, 1986). Nematode suspension was collected after $24 \mathrm{~h}$ and the numbers of nematodes were counted in five aliquots of $1 \mathrm{ml}$ of suspension from each sample. The means of five counts were used to calculate the population of nematodes per $\mathrm{kg}$ soil. To estimate the number of juveniles, eggs and females inside the roots, a $1 \mathrm{~g}$ subsample of roots was macerated in a Waring blender and counts were made from the suspension thus obtained. Numbers of nematodes present in roots were calculated by multiplying the number of nematodes present in $1 \mathrm{~g}$ of root by the total weight of root. Root rot and blight index was determined by scoring the severity of disease on visual observations of disease symptoms. Root rot symptoms were observed on roots while blight 
symptoms were observed on leaves. Disease rating was done on a scale ranging from 0 to 5 scale. Rotting symptoms were observed on the root where $0=$ no disease; $1=$ rotting symptoms up to $12.5 \%$ on root; $2=$ rotting 12.6 to $25 \%$ on root; $3=$ rooting 25.1 to 37.5 on root; $4=37.6$ to $50 \%$ on root; $5=$ more than $50 \%$ rooting on the root system. Similarly, blight symptoms were observed on the leaves where $0=$ no disease; $1=$ blight symptoms up to 12.5 leaves; $2=$ blight 12.6 to $25 \%$ on leaves; $3=$ blight 25.1 to 37.5 on leaves; $4=$ blight 37.6 to $50 \%$ on leaves; $5=$ more than $50 \%$ blight symptoms on leaves. The chlorophyll content and carotenoids in fresh leaves were estimated following the method of Mackinney (1941). The proline content in the fresh leaf samples was measured by the method of Bates et al. (1973).

\section{Statistical analysis}

Data obtained were analysed statistically by analysis of variance using http://hau. ernet.in/about/opstat.php (off campus user). The critical differences (C.D.) were calculated at $P \leq 0.05$. Duncan's multiple range test was employed to denote significant differences between the treatments. Means and standard errors of five replicates are given.

\section{Results}

Root dry weight

Plants grown in 20:80 and 40:60\% sand:clay mixture showed a significant increase in root dry weight over plants grown in 100\% clay soil (Table 1). However, use of 60:40 sand:clay resulted in a similar root dry weight as was found in plants grown with $100 \%$ clay. Inoculation with $M$. incognita, $A$. dauci or $F$. solani caused a significant reduction in root dry weight in all soil types as compared to their respective control. Inoculation with $M$. incognita, A. dauci or F. solani in $100 \%$ clay soil caused statistically a similar reduction in root dry weight. However, inoculation of $A$. dauci caused the greatest reduction in root dry weight followed by $F$. solani and $M$. incognita in different sand and clay mixtures. Root dry weight of $M$. incognita, A. dauci or $F$. solani-inoculated plants grown on 40:60 sand:clay mixture was statistically similar to that grown with 60:40 sand:clay (Table 1).

\section{Chlorophyll content}

Plants grown in 20:80 and 40:60\% sand:clay mixture caused a significant increase in chlorophyll content compared to plants grown in 60:40 sand and clay mixture respectively (Table 2). However, mixture of 60:40 sand:clay resulted in similar chlorophyll content as was found in plants grown in $100 \%$ clay soil. Inoculation with M. incognita, $A$. dauci or $F$. solani caused a significant reduction in chlorophyll content as compared to their respective control. However, A. dauci caused a greater reduction in chlorophyll content than F. solani or M. incognita in different sand and clay mixtures. Chlorophyll 
Table 1

Effects of Meloidogyne incognita, Alternaria dauci and Fusarium solani in different types of soil on the growth of carrot

\begin{tabular}{|c|c|c|c|c|c|}
\hline Treatments & Soil type & $\begin{array}{l}\text { Plant length } \\
\qquad(\mathrm{cm})\end{array}$ & $\begin{array}{l}\text { Plant fresh weight } \\
\text { (g) }\end{array}$ & $\begin{array}{l}\text { Shoot dry weight } \\
\text { (g) }\end{array}$ & $\begin{array}{l}\text { Root dry weight } \\
(\mathrm{g})\end{array}$ \\
\hline \multirow[t]{4}{*}{ Control } & Clay soil & $52.02^{\mathrm{e}} \pm 0.694$ & $63.9^{d} \pm 0.524$ & $2.03^{\mathrm{de}} \pm 0.066$ & $2.95^{\mathrm{bc}} \pm 0.069$ \\
\hline & Clay soil $+20 \%$ sand & $70.20^{\mathrm{a}} \pm 0.456$ & $69.42^{\mathrm{a}} \pm 0.535$ & $3.20^{\mathrm{a}} \pm 0.122$ & $3.40^{\mathrm{a}} \pm 0.149$ \\
\hline & Clay soil $+40 \%$ sand & $69.50^{\mathrm{a}} \pm 0.327$ & $67.30^{\mathrm{b}} \pm 0.363$ & $2.79^{\mathrm{b}} \pm 0.251$ & $3.31^{\mathrm{a}} \pm 0.097$ \\
\hline & Clay soil $+60 \%$ sand & $54.44^{\mathrm{cd}} \pm 0.369$ & $65.40^{c} \pm 0.241$ & $2.41^{\mathrm{c}} \pm 0.060$ & $3.16^{\mathrm{ab}} \pm 0.076$ \\
\hline \multirow{4}{*}{$\begin{array}{l}\text { Meloidogyne } \\
\text { incognita }\end{array}$} & Clay soil & $48.60^{\mathrm{fg}} \pm 0.298$ & $47.50^{f} \pm 0.472$ & $1.80^{\text {efg }} \pm 0.088$ & $1.44^{\mathrm{h}} \pm 0.043$ \\
\hline & Clay soil $+20 \%$ sand & $60.20^{\mathrm{b}} \pm 0.928$ & $49.80^{\mathrm{e}} \pm 0.378$ & $2.25^{\mathrm{cd}} \pm 0.083$ & $2.85^{\mathrm{c}} \pm 0.148$ \\
\hline & Clay soil $+40 \%$ sand & $56.00^{c} \pm 0.467$ & $48.70^{\mathrm{ef}} \pm 0.613$ & $2.08^{\text {de }} \pm 0.104$ & $3.01^{\mathrm{bc}} \pm 0.089$ \\
\hline & Clay soil $+60 \%$ sand & $49.48^{\mathrm{f}} \pm 0.411$ & $47.90^{f} \pm 0.376$ & $1.85^{\mathrm{ef}} \pm 0.080$ & $2.84^{\mathrm{c}} \pm 0.081$ \\
\hline \multirow{4}{*}{$\begin{array}{l}\text { Alternaria } \\
\text { dauci }\end{array}$} & Clay soil & $39.42^{\mathrm{i}} \pm 0.672$ & $35.20^{\mathrm{k}} \pm 0.274$ & $0.91^{\mathrm{k}} \pm 0.066$ & $1.19^{\mathrm{h}} \pm 0.041$ \\
\hline & Clay soil $+20 \%$ sand & $54.70^{\mathrm{cd}} \pm 0.212$ & $42.50^{\mathrm{h}} \pm 0.415$ & $1.45^{\mathrm{hij}} \pm 0.083$ & $2.15^{\mathrm{ef}} \pm 0.038$ \\
\hline & Clay soil $+40 \%$ sand & $53.50^{\mathrm{d}} \pm 0.511$ & $40.80^{i} \pm 0.207$ & $1.35^{\mathrm{ij}} \pm 0.059$ & $2.05^{\mathrm{fg}} \pm 0.047$ \\
\hline & Clay soil $+60 \%$ sand & $45.80^{\mathrm{h}} \pm 0.507$ & $38.40^{\mathrm{j}} \pm 0.354$ & $1.16^{\mathrm{jk}} \pm 0.075$ & $1.87^{\mathrm{g}} \pm 0.165$ \\
\hline \multirow{4}{*}{$\begin{array}{l}\text { Fusarium } \\
\text { solani }\end{array}$} & Clay soil & $45.40^{\mathrm{h}} \pm 0.635$ & $38.40^{\mathrm{j}} \pm 0.395$ & $1.27^{\mathrm{ij}} \pm 0.049$ & $1.30^{\mathrm{h}} \pm 0.037$ \\
\hline & Clay soil $+20 \%$ sand & $59.40^{\mathrm{b}} \pm 0.281$ & $45.12^{g} \pm 0.221$ & $1.68^{\mathrm{fgh}} \pm 0.087$ & $2.51^{\mathrm{d}} \pm 0.068$ \\
\hline & Clay soil $+40 \%$ sand & $55.70^{c} \pm 0.581$ & $42.90^{\mathrm{h}} \pm 0.756$ & $1.51^{\mathrm{ghi}} \pm 0.051$ & $2.39^{\mathrm{de}} \pm 0.093$ \\
\hline & Clay soil $+60 \%$ sand & $47.70^{g} \pm 0.580$ & $40.12^{\mathrm{i}} \pm 0.331$ & $1.32^{\mathrm{ij}} \pm 0.082$ & $2.19^{\mathrm{ef}} \pm 0.058$ \\
\hline C.D. $P \leq 0.05$ & & 1.48 & 1.21 & 0.28 & 0.25 \\
\hline
\end{tabular}

* Means \pm standard error of five replicates are shown

* Values in a column followed by the different letters are significantly different at $P \leq 0.05$ using Duncan's multiple range test

$*$ C.D. $=$ Critical difference

contents of $M$. incognita, A. dauci or F. solani-inoculated plants grown in 20:80 sand: clay mixture was statistically similar to that grown in 40:60 sand:clay (Table 2).

\section{Carotenoid content}

Plants grown 20:80 and 40:60\% sand:clay mixture caused a significant increase in carotenoid content compared to plants grown in clay soil (Table 2). Inoculation with M. incognita, A. dauci and F. solani caused a significant reduction in carotenoid content in all soil types as compared to their respective control. The one exception was the effect of $F$. solani in $100 \%$ clay soil. A. dauci and M. incognita caused the greatest reduction in carotenoid content followed by $F$. solani in different sand and clay mixtures. Carotenoid contents of $M$. incognita or A. dauci inoculated plants were statistically similar to each other in either of the four soil types (Table 2). 


\section{Proline content}

Addition of sand to clay soil caused a significant increase in proline content (Table 2). Increase in proline content was the greatest in plants grown in 60:40 sand:clay followed by 40:60 and 20:80\% sand:clay. Inoculation with M. incognita, A. dauci and $F$. solani caused a significant increase in proline content in all soil types compared to their respective control. A. dauci caused the greatest increase in proline content followed by F. solani and M. incognita (Table 2).

\section{Root galling and nematode multiplication}

Root galling and nematode multiplication was the greatest in plants grown in 40:60 sand and clay mixture followed by 60:40 sand:clay and 20:80 sand:clay mixture (Table 2). Least galling intensity and nematode multiplication was observed in plant grown in $100 \%$ clay soil.

\section{Disease indices}

Blight and root-rot indices were 3 when $A$. dauci and $F$. solani inoculated plants were grown in $100 \%$ clay soil (Table 2). Indices were observed 2 when A. dauci and F. solani were inoculated in other soil types.

\section{Discussion}

Soil characteristics play an important role in the plant's ability to extract water and nutrients. The soil must provide a satisfactory environment for plant to grow to their potential. Carrots like loose rich soil, preferably a little sandy. Loose sandy soil allows growing long slender straight carrots. Moreover, soil should be well drained and loose to prevent forking and stunting of the root growth. The highest growth of carrot, greater chlorophyll and carotenoid contents was observed in the 80:20 clay:sand mixture and may be due to optimum pore space, water holding capacity or aeration of the soil (Black, 1973).

Damage caused by nematodes is often proportionally greater in sandy soils where nematodes can move more freely, than in heavier soils where movement is impeded (Ravichandra, 2014). Adequate soil moisture is also essential for free movement to infect roots, therefore, plant growth, chlorophyll and carotenoid contents were also equally affected in different types of soils by nematode parasitism (Trudgill and Phillips, 1997). However, highest nematode multiplication was observed in 40:60 sand:clay mixture. High rate of nematode multiplication in 40:60 sand:clay may partly be due to higher content of coarse particles in the soil (Koenning et al., 1988). Increased pore size and soil characteristics are favourable for nematode movement and multiplication (Wallace, 1963). On the other hand, pure clay has unfavourable pore size and aeration which probably resulted in poor nematode multiplication and movement (Young and Heatherly, 1990). Low multiplication of nematodes in 60:40 sand:clay may be due to low water holding capacity (Wallace, 1963). 
Table 2

Effects of Meloidogyne incognita, Alternaria dauci and Fusarium solani in different types of soil on chlorophyll, carotenoid, proline contents, nematode galling and disease index

\begin{tabular}{|c|c|c|c|c|c|c|c|}
\hline Treatments & Soil type & $\begin{array}{l}\text { Total chloro- } \\
\text { phyll (mg/g) }\end{array}$ & $\begin{array}{l}\text { Carotenoid con- } \\
\text { tent }(\mathrm{mg} / \mathrm{g})\end{array}$ & $\begin{array}{l}\text { Proline content } \\
\qquad(\mu \mathrm{mol} / \mathrm{g})\end{array}$ & $\begin{array}{c}\text { No. of } \\
\text { galls/root }\end{array}$ & $\begin{array}{c}\text { Nematode } \\
\text { population } / \mathrm{kg} \\
\text { soil }\end{array}$ & $\begin{array}{l}\text { Blight/ } \\
\text { root-rot } \\
\text { index }\end{array}$ \\
\hline \multirow[t]{4}{*}{ Control } & Clay soil & $0.278^{\mathrm{cd}} \pm 0.004$ & $0.0508^{\mathrm{ef}} \pm 0.0010$ & $0.0761^{\mathrm{k}} \pm 0.0014$ & - & - & - \\
\hline & $\begin{array}{l}\text { Clay soil }+20 \% \\
\text { sand }\end{array}$ & $0.326^{\mathrm{a}} \pm 0.005$ & $0.0656^{\mathrm{a}} \pm 0.0011$ & $0.0831^{\mathrm{j}} \pm 0.0006$ & - & - & - \\
\hline & $\begin{array}{l}\text { Clay soil }+40 \% \\
\text { sand }\end{array}$ & $0.312^{\mathrm{b}} \pm 0.004$ & $0.0625^{b} \pm 0.0013$ & $0.0890^{i} \pm 0.0006$ & - & - & - \\
\hline & $\begin{array}{l}\text { Clay soil }+60 \% \\
\text { sand }\end{array}$ & $0.282^{\mathrm{cd}} \pm 0.004$ & $0.0540^{c} \pm 0.0010$ & $0.0949^{\mathrm{gh}} \pm 0.0006$ & - & - & - \\
\hline \multirow{4}{*}{$\begin{array}{l}\text { Meloidogyne } \\
\text { incognita }\end{array}$} & Clay soil & $0.256^{\mathrm{fg}} \pm 0.005$ & $0.0478^{\mathrm{gh}} \pm 0.0009$ & $0.0969^{\mathrm{fg}} \pm 0.0014$ & $81^{c} \pm 6.34$ & $10530^{\mathrm{d}} \pm 493.9$ & - \\
\hline & $\begin{array}{l}\text { Clay soil }+20 \% \\
\text { sand }\end{array}$ & $0.283^{\mathrm{c}} \pm 0.004$ & $0.0507^{\mathrm{ef}} \pm 0.0010$ & $0.0938^{\mathrm{h}} \pm 0.0005$ & $108^{\mathrm{b}} \pm 4.14$ & $14340^{\mathrm{c}} \pm 374.8$ & - \\
\hline & $\begin{array}{l}\text { Clay soil }+40 \% \\
\text { sand }\end{array}$ & $0.272^{\text {cde }} \pm 0.003$ & $0.0505^{\mathrm{ef}} \pm 0.0015$ & $0.1046^{\mathrm{e}} \pm 0.0008$ & $142^{\mathrm{a}} \pm 5.14$ & $18670^{\mathrm{a}} \pm 320.5$ & - \\
\hline & $\begin{array}{l}\text { Clay soil }+60 \% \\
\text { sand }\end{array}$ & $0.269^{\mathrm{def}} \pm 0.003$ & $0.0483^{\mathrm{gh}} \pm 0.0006$ & $0.1116^{\mathrm{d}} \pm 0.0007$ & $122^{\mathrm{b}} \pm 5.55$ & $15690^{\mathrm{b}} \pm 340.5$ & - \\
\hline \multirow{4}{*}{$\begin{array}{l}\text { Alternaria } \\
\text { dauci }\end{array}$} & Clay soil & $0.222^{\mathrm{i}} \pm 0.005$ & $0.0473^{\mathrm{h}} \pm 0.0011$ & $0.1039^{\mathrm{e}} \pm 0.0010$ & - & - & 3 \\
\hline & $\begin{array}{l}\text { Clay soil }+20 \% \\
\text { sand }\end{array}$ & $0.269^{\mathrm{def}} \pm 0.005$ & $0.0506^{\mathrm{ef}} \pm 0.0014$ & $0.1147^{c} \pm 0.0007$ & - & - & 2 \\
\hline & $\begin{array}{l}\text { Clay soil }+40 \% \\
\text { sand }\end{array}$ & $0.252^{\text {gh }} \pm 0.004$ & $0.0492^{\mathrm{fgh}} \pm 0.0006$ & $0.1257^{b} \pm 0.0009$ & - & - & 2 \\
\hline & $\begin{array}{l}\text { Clay soil }+60 \% \\
\text { sand }\end{array}$ & $0.241^{\mathrm{h}} \pm 0.006$ & $0.0486^{\mathrm{gh}} \pm 0.0013$ & $0.1347^{\mathrm{a}} \pm 0.0008$ & - & - & 2 \\
\hline \multirow{4}{*}{$\begin{array}{l}\text { Fusarium } \\
\text { solani }\end{array}$} & Clay soil & $0.251^{\mathrm{gh}} \pm 0.004$ & $0.0496^{\mathrm{efg}} \pm 0.0012$ & $0.0985^{\mathrm{f}} \pm 0.0017$ & - & - & 3 \\
\hline & $\begin{array}{l}\text { Clay soil }+20 \% \\
\text { sand }\end{array}$ & $0.273^{\text {cde }} \pm 0.005$ & $0.0531^{\mathrm{cd}} \pm 0.0007$ & $0.1062^{\mathrm{e}} \pm 0.0008$ & - & - & 2 \\
\hline & $\begin{array}{l}\text { Clay soil }+40 \% \\
\text { sand }\end{array}$ & $0.262^{\mathrm{efg}} \pm 0.004$ & $0.0517^{\mathrm{de}} \pm 0.0010$ & $0.1131^{\mathrm{cd}} \pm 0.0010$ & - & - & 2 \\
\hline & $\begin{array}{l}\text { Clay soil }+60 \% \\
\text { sand }\end{array}$ & $0.258^{\mathrm{fg}} \pm 0.005$ & $0.0496^{\mathrm{efg}} \pm 0.0011$ & $0.1270^{\mathrm{b}} \pm 0.0006$ & - & - & 2 \\
\hline C.D. $P \leq 0.05$ & & 0.012 & 0.0021 & 0.0027 & 16.2 & 1174.2 & - \\
\hline
\end{tabular}

*Means \pm standard error of five replicates are shown

*Values in a column followed by the different letters are significantly different at $P \leq 0.05$ using Duncan's multiple range test

*C.D.=Critical difference

In the present study we found greater incidence of blight and root rot incidence in 
clay soil than in the mixtures of sand and clay. Similarly, Kuldhar et al. (2013) observed greater wilt incidence in clay soil followed by sandy loam and sandy soil. In contrast, Sagar and Sugha (1998) reported high pea wilt incidence in silty loam soil $(85.70 \%)$ followed by sandy loam soil $(84.70 \%)$ and clay soil $(78.50 \%)$. Soil, on the basis of different particle size distribution, $\mathrm{pH}$, cation exchange capacity, or organic matter content, thus can affect microbial community structure either directly, i.e. by providing a specific habitat that selects specific microorganisms, or indirectly, i.e. by affecting plant root functioning and exudation in a soil-specific manner (Garbeva et al., 2004). The mechanisms by which soils are suppressive to different pathogens, although not always clear, can involve biotic (soil microflora) and/or abiotic factors (soil physicochemical properties); they may vary with the pathogen. Fluctuations in soil moisture content might confound the principles and the relationships between the plant and soil types may influence microbial community (Garbeva et al., 2004). The differences observed in different studies may be due to different crops/different pathogens used.

Proline is a multi-functional amino acid which confers tolerance to plants against abiotic stresses (Szabados and Savoure, 2010) and has been correlated to plant defense against pathogens (Cecchini et al., 2011; Senthil-Kumar and Mysore, 2012). Plant accumulates proline by increasing its synthesis and reducing catabolism under abiotic stresses (Kishor et al., 2005; Verbruggen and Hermans, 2008). Proline content was increased with the increase in the sand concentration in soil. We have found that pathogen inoculation also increased proline contents, possibly due to plant defense against pathogen (Fabro et al., 2004; Verslues and Sharma, 2010). Studies have shown that proline catabolism is enhanced during early stages of plant defense against invading pathogens (Cecchini et al., 2011). Increase in proline contents in carrots grown in different types of soil and after inoculation of pathogens is probably both due to abiotic and biotic stress.

\section{Literature}

Abawi, G. S., Ludwig, J. W. and Gugino, B. K. (2009): Nematode research update and management practices. Empire State Fruit and Vegetable Expo Proc., Cornell Coop. Extension, 54-57.

Al-Harbi, A. R., Alsadon, A. A. and Khalil, S. O. (1997): Influence of planting date upon growth and objective component of two carrot cultivars grown in Riyadh region of Saudi Arabia. J. King Saudi. Univ. Agric. Sci. 9, 257-266.

Bates, L., Waldren, R. P. and Teare, I. D. (1973): Rapid determination of free proline for water-stress studies. Plant Soil, 39, 205-207.

Black, C. A. (1973): Soil Plant Relationships. Wiley, New Delhi, 792 p.

Cecchini, N. M., Monteoliva, M. I. and Alvarez, M. E. (2011): Proline dehydrogenase contributes to pathogen defense in Arabidopsis. Plant Physiol. 155, 1947-1959. 10.1104/pp.110.167163

Fabro, G., Kovacs, I., Pavet, V., Szabados, L. and Alvarez, M. E. (2004): Proline accumulation and AtP5CS2 gene activation are induced by plant-pathogen incompatible interactions in Arabidopsis. Mol. Plant Microbe Interact. 17, 343-350. 10.1094/MPMI.2004.17.4.343

Garbeva, P., Veen, J. A. V. and Elsas, J. D. V. (2004): Microbial diversity in soil: selection of microbial populations by plant and soil type and implications for disease suppressiveness. Annu. Rev. Phytopathol. 42, 243-270. 
Kishor, P. K., Sangam, S., Amrutha, R. N., Laxmi, P. S., Naidu, K. R., Rao, K. R. S. S. et al. (2005): Regulation of proline biosynthesis, degradation, uptake and transport in higher plants: its implications in plant growth and abiotic stress tolerance. Curr. Sci. 88, 424-438.

Koenning, S. R. and Barker, K. R. (1995): Soybean photosynthesis and yield as influenced by Heterodera glycines, soil type and irrigation. J. Nematol. 27, 51-62.

Koenning, S. R., Anand, S. C. and Wrather, J. R. (1988). Effect of within-field variation in soil texture on $\mathrm{He}$ terodera glycines and soybean yield. J. Nematol. 20, 373-380.

Koike, S. T., Gladders, P. and Paulus, A. O. (2006): Vegetable Diseases. 1st ed. A Color Handbook. Elsevier Science. ISBN-13: 9780123736758.320 p..

Kuldhar, D. P., Badgujar, S. L. and Dey, U. (2013): Effect of different soil types on the incidence of pea wilt (Pot culture). Internat. J. Plant Sci., 8, 456-457.

Mackinney, G. (1941): Absorption of light by chlorophyll solutions. J. Biol. Chem. 140, 315-322.

Ravichandra N. G. (2014): Horticulture Nematology. Springer, India. ISBN-13: 978-81-322-1841-8. 412 p.

Riker, A. J. and Riker, R. S. (1936): Introduction to Research on Plant Diseases. John Swift Co. Inc. Ioris, 11 176. 6.

Rubatzky, V. E., Quiros, C. F. and Simon, P. W. (1999): Carrots and Related Vegetable Umbelliferae. Crop Production Science in Horticulture. CABI Publishing, Wallingford, UK. Vol. 10, 304 p.

Sagar, V. and Sugha, S. K. (1998): Effect of soil types and available nutrients on fusarial population and severity of pea wilt. J. Mycol. Pl. Pathol., 28, 199-294.

Sasser, J. N. and Carter, C. C. (1985): An advanced treatise on Meloidogyne. Vols I, II. North Carolina State University Graphics, Raleigh, NC, USA.

Senthil-Kumar, M. and Mysore, K. S. (2012): Ornithine-delta-aminotransferase and proline dehydrogenase genes play a role in non-host disease resistance by regulating pyrroline-5-carboxylate metabolism-induced hypersensitive response. Plant Cell Environ. 35, 1329-1343. 10.1111/j.1365-3040.2012.02492.x

Southey, J. F. (1986): Laboratory methods for work with plant and soil nematodes. Ministry of Agric. Fisheries and Food HMSO, London, 202 p.

Szabados, L. and Savoure, A. (2010): Proline: a multifunctional amino acid. Trends Plant Sci. 15, 89-97. 10.1016/j.tplants.2009.11.009

Trudgill, D. L. and Phillips, M. S. (1997): Nematode population dynamics, threshold levels and estimation of crop losses. FAO Plant Production and Protection Paper-144.

Verbruggen, N. and Hermans, C. (2008): Proline accumulation in plants: a review. Amino Acids 35, $753-759$. 10.1007/s00726-008-0061-6

Verslues, P. E. and Sharma, S. (2010): Proline metabolism and its implications for plant-environment interaction. Arabidopsis Book 8:e140 10.1199/tab.0140

Wallace, H. R. (1963): The Biology of Plant Parasitic Nematodes. Edward Arnold, London, 280 p.

Yawalker, K. S. (1992): Vegetable Crops of India (4 ${ }^{\text {th }}$ ed.). Agri-Horticultural Publishing House, Nagpur, India, 68 p.

Young, L. D. and Heatherly, L. G. (1990): Heterodera glycines invasion and reproduction of soybean grown in clay and silt loam soils. J. Nematol. 22, 618-619. 